\title{
Polypharmacy in schizophrenia - therapeutic option or a sign of despair?
}

\author{
Anastasios Konstantinidis \\ From $1^{\text {st }}$ International Congress on Neurobiology and Clinical Psychopharmacology and European \\ Psychiatric Association Conference on Treatment Guidance \\ Thessaloniki, Greece. 19-22 November 2009
}

International guidelines on schizophrenia and worldwide experts in psychiatry recommend and insist on monotherapy with an antipsychotic medication for schizophrenic patients. Studies about the clinical practice of these guidelines show that all over the world most schizophrenia patients receive two or more antipsychotics. Further more combinations with antidepressants, mood stabilizers or benzodiazepines is also common. Regarding to local national differences polypharmacy rates are increasing and achieve rates between 50 and $90 \%$ of schizophrenic patients, exhibiting therefore a major international trend towards polypharmacy. Although in some cases combination therapy brings advantages, such as "enhancing" or "speeding up" the antipsychotic effect, there are still a lot of disadvantages in a polypharmacy treatment regiment, such as interactions of the drugs being involved, the greater risk of adverse reactions and the lack of compliance to treatment regiment. Small, randomised controlled studies with regard to antipsychotic combination therapy exist. In summary they exhibit a positive outcome for combinations of antipsychotics with different receptor profile. Altogether according to the study results combinations can be divided in irrational (e.g. clozapine and quetiapine), and rational ones, which provide a greater efficacy (e.g. clozapine and amisulpirid). Augmentation with antidepressant agents in case of persisting negative symptoms and with mood stabilizers in patients with additional affective symptoms can be recommended. Further randomised controlled studies are necessary to recommend combination strategies on a higher level of evidence for treatment resistant schizophrenia patients. In the speech given, I would try to give you an overview and discuss

University Hospital for Psychiatry and Psychotherapy, Clinical Division for Biological Psychiatry, Vienna, Austria current data and trends in combining antipsychotic or other psychotropic treatment in schizophrenia.

Published: 22 April 2010

doi:10.1186/1744-859X-9-S1-S70

Cite this article as: Konstantinidis: Polypharmacy in schizophrenia therapeutic option or a sign of despair?. Annals of General Psychiatry 2010 9(Suppl 1):S70.
Submit your next manuscript to BioMed Central and take full advantage of:

- Convenient online submission

- Thorough peer review

- No space constraints or color figure charges

- Immediate publication on acceptance

- Inclusion in PubMed, CAS, Scopus and Google Scholar

- Research which is freely available for redistribution

Submit your manuscript at www.biomedcentral.com/submit
Biomed Central 